\title{
Environmental impact of women exploitation of forest resources in some forest reserves in Osun State, Nigeria
}

\begin{abstract}
Loss of forest resources in Nigeria is between $2.6 \%$ and 3.5\% per annum. Thus, an investigation on the effects of utilization of forest resources by women in five forest reserves, namely; Oba Hill, Ago-Owu, Shasha, Ife Native and Ikeji-Ipetu Forest Reserves in Osun State was conducted. Five hundred questionnaires were administered across the five locations at an average of one hundred per study area. Focus Group Discussions were also carried out as data quality control measure. Data analysis adopted tabulation, frequency distribution and percentages. The results across the five locations showed that the total proportion of live woody forest products collected was $19.0 \%$ higher than $14.8 \%$ of dry woody forest products collected with FGDs revealing that $87.2 \%$ did not bother about replanting. The implication of these findings is that more land areas were opened up to direct run-off and solar radiation through the cutting and collection of live trees, the situation suggesting that forest degradation is on course in the area with no interest in replacing trees removed among the respondents. It is therefore, recommended that alternative sources of energy should be introduced and made available to the women in the study area to minimise forest trees removal and to avert energy source-related crisis. Also, appropriate legislation should be put in place to protect the forest from further depletion and women are enlightened on environmental degradation caused by forest live trees removal.
\end{abstract}

Volume 4 Issue 4 - 2019

\author{
Asifat Janet Temitope,' Ogunbode, Timothy \\ Oyebamiji \\ 'Department of Geography, Obafemi Awolowo University, Nigeria \\ ${ }^{2}$ Department of Environmental Management and crop production, \\ Bowen University, Iwo \\ Correspondence: Asifat Janet Temitope, Department of \\ Geography, Obafemi Awolowo University, Ile-lfe, Nigeria,Tel \\ 08032260566, Email janetasifat@yahoo.com
}

Received: July 22, 2019 | Published: August 06, 2019

Keywords: forest resources, forest utilization, environmental degradation, forest reserves, Osun State

Abbreviations: IPCC, intergovernmental panel on climate change; UNDP, United Nations development programme; FRs, Forest Reserves; FGDs, Focus group discussions

\section{Introduction}

Forests cover close to 4 billion hectares (30\%) of the earth's land surface. ${ }^{1}$ It plays important roles in the functioning of the biosphere and indirectly affects provision of other goods and services such as timber production, fruit, herb etc. ${ }^{2}$ More than 1.6 billion people rely on forests for their livelihoods at various levels in terms of gathering of forest resources such as firewood, non- timber forest products like fruits, nuts, broom, vegetables, leaves and medicinal plants and so on are either for consumption or for sale to cater for their domestic needs. According to Coulibaly- Lingani et al., ${ }^{3}$ about $75 \%$ of women use forest globally because of their roles as carers and those who cook for the family. Also Angelsen, ${ }^{4}$ Asifat ${ }^{5}$ revealed that women are considered as primary users of the forest since they are involved in collection of different products (timber and non-timber) from the forest. Due to world population increase there is immeasurable pressure on the requirement of forest products for numerous needs which ${ }^{6}$ claimed to have resulted in the destruction of forest cover. Also, unmonitored harvesting of forest resources leads to shrinking forests and destruction of the habitat within which plants and wildlife live. Aderopo ${ }^{7}$ argued that forest destruction has been linked to economic decline of forest communities and global climate change which needs to be halted while in 2012, Asifat, ${ }^{8}$ traced gases and aerosols that are released during bush burning to continuous search for firewood in developing countries. This view was equally corroborated by Fearnside, ${ }^{9}$ when he stated that global warming is partly attributed to deforestation.

According to Intergovernmental Panel on Climate Change (2001) (IPCC) ${ }^{10}$ deforestation, mainly in tropical areas, could account for up to one-third of total anthropogenic carbon dioxide emissions. Deforestation may also cause carbon stores held in soil to be released. This attitude seems unabated in developing nations in view of the discovery of United Nations Development Programme (UNDP) ${ }^{11}$ which noted that women being traditionally primary care givers in homes depend largely on forest resources for their living, especially as source of fuelwood for cooking purposes. Probably, this could have partly explained the report of Federal Department of Forestry (2001) and FAO, ${ }^{1}$ which lamented on the forest resources, especially the woody products, being destroyed at an alarming rate globally. The problem is even worse in developing countries and importantly, in the tropical world according to World Bank (1992) as the rate of deforestation seems uncontrollable, Omoleye and Orimoogunje ${ }^{12}$ in corroborating this view revealed that the depletion of forest resources in Nigeria, Osun State inclusive, is being estimated to be between $2.6 \%$ and $3.5 \%$ per annum leading to the suggestion that the remaining forest areas of the country would totally disappear within the next three decades.

Thus, this research work aims to assess the role of women in environmental degradation through their exploitation on forest resources in five Forest Reserves in Osun State, Nigeria. Specific objectives are to: 
1) Assess the forest resources being exploited by women in the study area

2) Examine the roles of women in forest resource degradation and its amelioration in the study area and

3) Assess the implications of women exploitation of forest resources.

\section{Materials and methods}

\section{Study area}

Osun State is endowed with eleven Forest Reserves (FRs) located across the State out of which five were selected for the purpose of this research (Figure 1). The selected FRs are Ago-Owu, Ikeji-Ipetu, Oba Hill, Shasha and Ife Native Authority FRs. Ago-Owu FR was found at approximately latitudes $7^{\circ} 8^{\prime}$ and $7^{\circ} 11^{\prime}$ North and longitudes $4^{\circ} 5^{\prime}$ and $4^{\circ} 23^{\prime}$ East and the land area initially covers $307.25 \mathrm{~km}$ square but remains $272.03 \mathrm{~km}$ square. Ikeji-Ipetu FR was found on latitude $7.400000 \mathrm{~N}$ and longitude $4.933333 \mathrm{E}$ covers 2849 hectare of land and Oba Hill forest reserve was found between latitude $7^{\circ} 39^{\prime} \mathrm{N}$ and longitude $4^{\circ} 9^{\prime} \mathrm{E}$ and covers 4224 hectare of land. Shasha FR was found in between latitudes $7^{\circ}-7.10^{\circ} \mathrm{N}$ and longitudes $4.20^{\circ}-4.40^{\circ} \mathrm{E}$ and covers 23064 hectare of land and Ife Native Authority FR was found between latitude $7^{\circ} 4^{\prime} \mathrm{N}$ and $7^{\circ} 15^{\prime} \mathrm{N}$ and longitude $4^{\circ} 19^{\prime} \mathrm{E}$ to $4^{\circ} 28^{\prime} \mathrm{E}$ and occupies a total land area of 100.084 sq. $\mathrm{km}$.

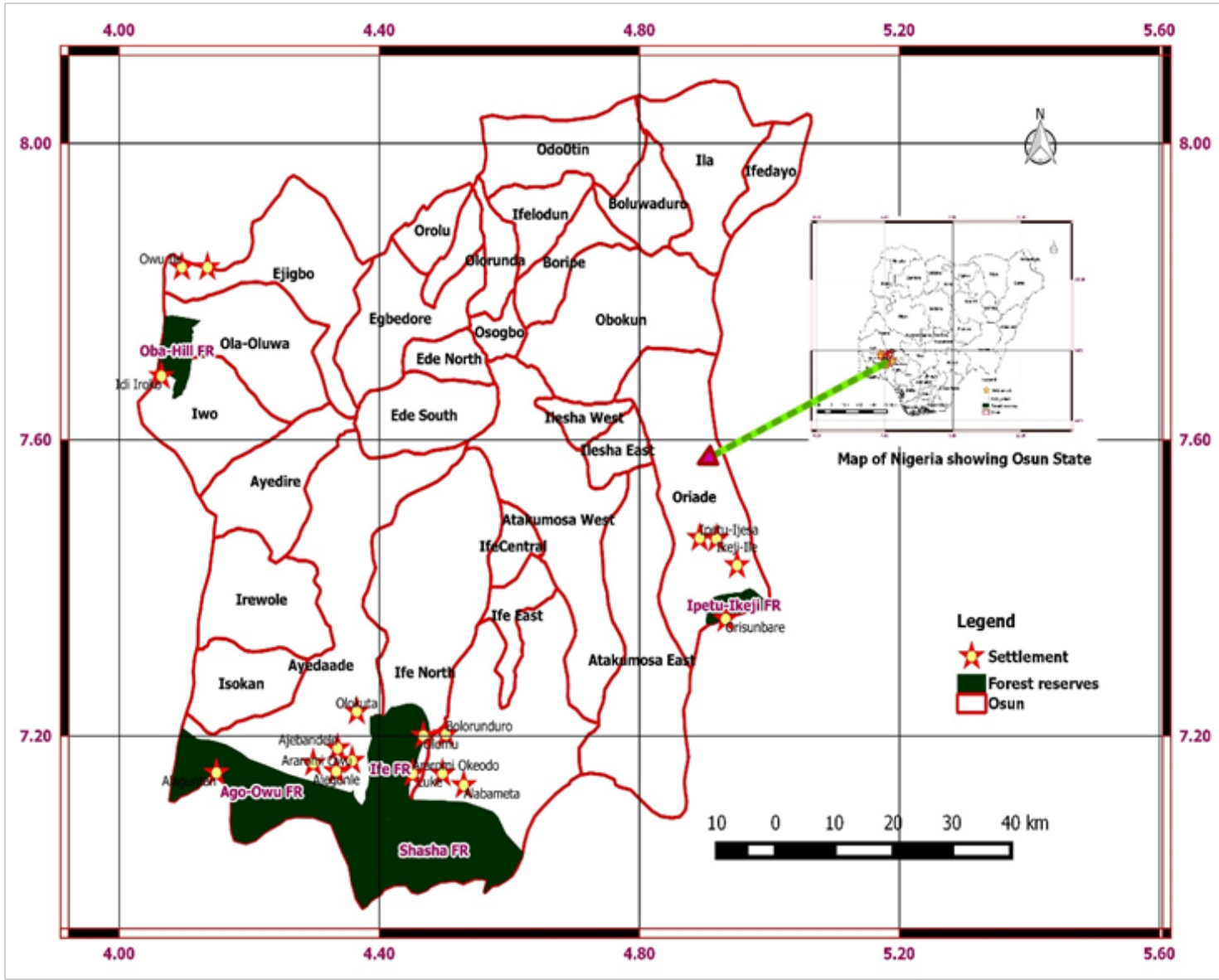

Figure I Map of Osun State showing the selected forest reserves.

\section{Methods of data collection and analysis}

Five villages located in the vicinity of the selected five FRs were selected for the purpose of this investigation giving a total of 25 villages. The villages were selected based on their ease of accessibility. Thus, those villages that fall within 5 to $7 \mathrm{~km}$ from the forests were investigated. One hundred households each were selected from each forest reserve, thus a total of five hundred questionnaires were administered for household survey. Married women that have lived in the area for not less than two decades were purposely targeted for this survey because of the belief in their possible enormous experiences and familiarities with the forest around them and the exploitation of resources therein in. In addition, fifty women (50) with ten from each of the five villages from Forest Reserve were selected for the purpose of Focus Group Discussions (FGDs) to ensure the quality control of the data generated from the questionnaire administration.

Data collected were subjected to mainly descriptive statistical analysis such as tabulation, frequency distribution and percentages.

\section{Results and discussion}

\section{Forest resources collected by women}

Table 1 shows that fuelwood collection, of all other forest products, ranked highest among other resources that were being collected and utilised by women across the villages investigated with $20.4 \%$ while collection of fruits ranked second with $15 \%$, medicinal plants came third with $13.8 \%$. Collection of leaves $13.4 \%$, wild animals such as 
snail, $5.6 \%$, timber $3.8 \%$, honey $2.2 \%$, sap and latex $1.6 \%$ and poles which ranked least of all the forest products collected by women with $0.8 \%$. The results showed that collection of leaves and medicinal plants take the lead of all other products in Ago-Owu. In Shasha, medicinal plants and fuelwood dominate forest products being collected with 18 and 16 out of hundred respectively. In Ife Native, fruits topped other forest resources with 18 medicinal plants 15 out of hundred. Collection of latex, poles and honey ranked least of all forest products being collected by women across the study area. For instance, collection of live poles in Ago-Owu and Ife Native Authority is (0) zero suggesting that the forest is depleted of young woody plants. Generally, the result suggested that women go into the FRs majorly for collection of fuelwood probably it was the main source of energy available to them. Also, collection of medicinal plants, leaves fruits are equally significant to women in the study area suggesting that people possibly depend on herbs for healthcare purposes, wrapping of food using leaves and eating and selling of fruits. Even though, honey and wild animals (e.g. snail) are collected from the forest by women, the proportion of 5.6 out of hundred across the study area. However, the results shows that collection of woody products altogether (timber, fuelwood, medicinal plants and poles) from the forest was $38.8 \%$ while non- woody products (honey, sap/latex, leaves, animals and fruits) was $37.8 \%$ across the FRs. Furthermore, collection of fuelwood ranked highest in both Oba Hill and Ikeji-Ipetu Forest Reserves with 32 and 30 out of hundred respectively. The result implies that, forest is being depleted of woody plants which could jeopardise the environmental quality in the area. This observation was also supported by Austin et al. ${ }^{13}$ and Asifat. ${ }^{5}$ Both authors reported in their respective studies that, firewood is the major source of energy and heavy dependency on it combined with rapid population growth has contributed to increased forest and woodland destruction.

Table I Forest resources utilization by women in the selected FRs

\begin{tabular}{lllllll}
\hline Forest resources utilization & & & & \\
\hline Option & Oba Hill & Ikeji & Ago-Owu Shasha & Ife & $\{(\mathbf{a}+\mathbf{b}+\mathbf{c}+\mathbf{d}+\mathbf{+}) / \mathbf{5 0 0} \%$ \\
\hline Timber & 2 & 4 & 4 & 5 & 4 & 3.8 \\
Honey & 3 & 2 & 1 & 2 & 3 & 2.2 \\
Fuelwood & 32 & 30 & II & 16 & 13 & 20.4 \\
Sap/Latex & 2 & 0 & 2 & 1 & 3 & 1.6 \\
Leaves & 9 & 7 & 26 & 11 & 14 & 13.4 \\
Medicinal Plant & 7 & 10 & 19 & 18 & 15 & 13.8 \\
Animal(snail) & 2 & 4 & 7 & 7 & 8 & 5.6 \\
Fruit & 10 & 13 & 19 & 15 & 18 & 15 \\
Poles & 1 & 2 & 0 & 1 & 0 & 0.8 \\
\hline
\end{tabular}

Source:Author's fieldwork, 2017

\section{Report of focus group discussion}

Table 2 reveals the report of FGDs across the villages being investigated. The report revealed that women also engage in activities such as felling of firewood, gathering of fruits and subsistence farming in the forest reserves in the area. The respondents visit to the forest reserves for collection of fuelwood was seldom but the quantity of firewood collected at a time was not mentioned. From the FGDs, it was clear that women collect firewood more than any other resources as discovered in questionnaire administered. This observation, if continued unabated may exacerbate environmental damage.

\section{Types of firewood gathered by women}

Table 2 shows that $66 \%$ of the respondents collected dry but fallen tree branches, $14.8 \%$, cutting and collection of dry but standing trees and shrubs, altogether refer to as dead forest products, $16.2 \%$, cutting and collection of wet tree branches and $2.8 \%$ cutting and collection of wet but standing trees /shrubs, altogether refer to as live forest products. This reveals that, cutting and collection of live forest products (wet tree branches and whole wet trees combined) was 19\% higher than $14.8 \%$ of dry but standing trees and shrubs in the forest. Thus, implying that forest depletion is on the increase in the study area because the removal of wet trees especially the standing ones mean that the forest is being cleared of growing trees. Apart from this, the cutting and collection of wet woody products in the forest might be as a result of gross inadequacy of dry woods. The situation found in this forest reserve may degenerate to energy source related crisis if not checkmated. Yaya ${ }^{14}$ and Orimoogunje ${ }^{12}$ reported that forest is being cleared at alarming rate because cutting down of wet wood seems unchecked in Nigeria whether for commercial purposes or home use.

Collection of wet tree branches and that of whole trunk combined together was highest in Ago-Owu (20, 4), followed by Oba Hill (18, $2)$, Shasha $(17,2)$, Ife Native $(13,4)$ and the least was Ikeji-Ipetu 13 and 2 respectively. It is observed that collection of dry trees, shrubs and branches are also dominant in the study area. The collection of these dries trees whether standing or fallen ones were less significant to the forest luxuriant and density because they are dead already. Forest depletion is highest in Ago-Owu with 24 20,4) out of hundred (Table 3). 
Table 2 Report of focus group discussion

\begin{tabular}{|c|c|c|c|c|c|c|}
\hline Issues & Option & Oba Hill & Ago- Owu & Ikeji- Ipetu & Shasha & Ife \\
\hline \multirow{5}{*}{$\begin{array}{l}\text { Activities of women in the } \\
\text { forest Reserves }\end{array}$} & Low & + & + & + & + & + \\
\hline & Firewood (domestic) & + & ++ & ++ & + & + \\
\hline & Firewood (commercial) & - & - & - & - & - \\
\hline & Timber logging & - & - & - & + & + \\
\hline & Poles & - & + & - & + & - \\
\hline \multirow[t]{7}{*}{$\begin{array}{l}\text { Involvement in forest } \\
\text { resources utilisation }\end{array}$} & Charcoal & - & - & - & - & - \\
\hline & Animal (Snail gathering) & - & + & + & + & + \\
\hline & Medicinal plants & + & ++ & + & ++ & ++ \\
\hline & Fruits & + & ++ & + & ++ & ++ \\
\hline & Leaves for wrapping purposes & + & ++ & + & ++ & ++ \\
\hline & Firewood fetching & + & + & + & + & + \\
\hline & Bush burning & + & + & + & - & - \\
\hline \multirow{4}{*}{$\begin{array}{l}\text { Roles of women in forest } \\
\text { degradation }\end{array}$} & Leave gathering & + & ++ & + & ++ & + \\
\hline & Logging & - & - & - & + & + \\
\hline & Medicinal plants & + & + & - & + & + \\
\hline & Frequently & + & + & + & + & + \\
\hline \multirow{2}{*}{$\begin{array}{l}\text { Frequency of Forest } \\
\text { Resources collection }\end{array}$} & Seldom & ++ & + & ++ & ++ & + \\
\hline & Not at all & ++ & ++ & ++ & ++ & ++ \\
\hline
\end{tabular}

Note: ++ , indicated where an opinion was emphasized; +, indicated where an opinion was mere identified; -, indicated where an opinion was not mentioned

Table 3 Type of firewood gathered by women

\begin{tabular}{|c|c|c|c|c|c|c|}
\hline & Oba Hill & Ikeji-ipetu & Ago-Owu & Shasha & Ife & $\%$ \\
\hline Dry standing tree/shrub & II & 18 & 15 & 17 & 13 & 14.8 \\
\hline Dry and fall tree branches & 69 & 67 & 60 & 63 & 71 & 66 \\
\hline Wet tree branches & 18 & 13 & 20 & 17 & 13 & 16.2 \\
\hline Whole wet trunk/shrub & 2 & 2 & 4 & 2 & 4 & 2.8 \\
\hline Total & 100 & 100 & 100 & 100 & 100 & \\
\hline
\end{tabular}

Source:Authors' field work

\section{Contribution of women to enhancing forest resources}

Table 4 shows the response of respondents to afforestation exercise. The general response showed that $87.2 \%$ of the women did not engage in planting tree while, $12.8 \%$ does. This finding could endanger the sustainability of forest resources especially trees. The response to replanting of trees by women in the study areas showed that IkejiIpetu and Shasha with 94\% each, Oba Hill 91\%, Ife 88\% and AgoOwu $79 \%$ indicating that vast majority of women in the area were more concerned with collection of forest trees but less bothered with the replacement. This observation was in contrary to Shuaibu (2015) who observed that women are very active in afforestation practices because of the benefits derived from it in a study carried out in Kogi State, Nigeria. However, Amani ${ }^{15}$ in supporting the findings in this work stated that women were not involved in reaforestation practices, and thus stated that women should be encouraged to participate in afforestation activities to enhance the sustainability of our forest. 
Table 4 Response of women to afforestation

\begin{tabular}{|c|c|c|c|c|c|c|c|}
\hline Option & Oba Hill & Ikeji & Ago-Owu & Shasha & Ife & $\%$ & Variance \\
\hline \multicolumn{8}{|c|}{ Tree Planting } \\
\hline Yes & 9 & 6 & 21 & 6 & 12 & 12.8 & \multirow{2}{*}{0.13} \\
\hline No & 91 & 94 & 79 & 94 & 88 & 87.2 & \\
\hline
\end{tabular}

\section{Conclusion}

This study examined forest resources utilization by women in five Forest Reserves in Osun State namely Ago-Owu, Ikeji-Ipetu, Oba Hill, Shasha and Ife Native Authority FRs.. Household survey and FGDs employed in this study revealed that major forest resources utilized by women was firewood and all kinds of firewood were gathered both wet and dry, branches and whole trunks. The situation in this area suggested the possibility of energy-related crisis in view of the increased collection of live woody products from the forest by the women which may be due to gross inadequacy of dry woody products, especially as source of energy. Also, the study showed that women participation in reforestation was low (\%) across the study area. This situation portends a serious danger to the environment since removal of trees from the forests exposes the soil to direct surface wash and also induces high temperature. It is therefore recommended that efforts should be geared towards educating women in the area, instituting relevant policies to minimise encroaching into the forest in search of firewood. Introducing other alternative sources of energy could help in this regard. Further research in this area is suggested especially what the utilisation of forest resources by women may imply especially on soil fertility, wild animals, food security among others.

\section{Acknowledgments}

None.

\section{Funding}

None.

\section{Conflicts of interest}

The authors declare that there is no competing of interest.

\section{References}

1. Food and Agriculture Organization. Global forest resources assessment (FRA) 2005. Rome: FAO; 2005.

2. Egbule CL. Gender vulnerability and adaptation strategies to climate change impacts on agriculture in the Niger Delta region of Nigeria. Unpublished Ph.D. Thesis, Department of Agricultural Extension, Nigeria: University of Nigeria; 2014.
3. Coulibaly- Lingani P, Savadogo P, Tigabu M, et al. Factors influencing people's participation in the forest management program in Burkina Faso, West Africa. Forest Policy and Economics. 2011;13(4):292-302.

4. Angelsen A, Wunder S. Exploiting the forest poverty link: key concepts, issues and research implications. CIFOR occasional paper no. 40. Bogor, Indonesia: Centre for International Forestry Research; 2003. 58 p.

5. Asifat JT. Assessment of women participation in forest resources utilization and management strategies in Osun State, Nigeria. Unpublished $\mathrm{PhD}$. Thesis, Ile-Ife, Nigeria: Obafemi Awolowo University; 2018.

6. Shuaibu RB. Women's involvement in forestry practices as livelihood options in Igalamela/Odolu Local Government area, Kogi State, Nigeria. JFEWR Publications; 2015. ISBN: 2141-1778.

7. Aderopo A. Community-based forest management in Buru, Taraba State, Nigeria. Journal of Environment and Earth Science. 2013;3(12).

8. Asifat JT. Ecological implications of fuelwood consumption in iwo local Government area, Osun State. Unpublished M.Sc. Thesis, Ili- Ife, Nigeria: Obafemi Awolowo University; 2012.

9. Fearnside Philip M, Laurance William F. Tropical deforestation and greenhouse-gas emissions. Ecological Applications. 2004;14 (4):982986.

10. IPCC. Climate change 2007: synthesis report. 2001.

11. UNDP. Climate change. 2013.

12. Orimoogunje OOI. Forest cover changes and land use dynamics in oluwa forest reserve, South-Western Nigeria. Journal of Landscape Ecology. 2014;7(2):25-44.

13. Austin NN, Sodienye AA, Nkasiobi SO, et al. Gender, forest resources management and sustainable household economies in South- Eastern Nigeria. IJRMEC. 2012;2(7).

14. Yaya SB. The development and adoption of local alternative sources of energy against fuel wood. A paper presented at a two day training workshop on Agro forestry management, for sustainable agricultural production; Manpower development centre. Kano State, Nigeria: Office of the Head of service; 2002:129-130.

15. Amani ARK. Local people attitudes towards community forestry practices: a case study of kosti province-central Sudan. International J Forestry Research. 2012;(6):516-523. 